REPORTS OF MORPHOLOGY
Official Journal of the Scientific Society of Anatomists,
Histologists, Embryologists and Topographic Anatomists
of Ukraine
journal homepage: https://morphology-journal.com

\title{
Morphofunctional changes in kidneys of rats with gentamicin- induced acute kidney injury and use of melatonin
}

Dudka Ye.A., Zamorskii I.I., Petriuk A.Ye., Shchudrova T.S.

Higher State Educational Establishment of Ukraine "Bukovinian State Medical University", Chernivtsi, Ukraine

ARTICLE INFO

Received: 17 November, 2017

Accepted: 10 January, 2018

UDC: $615.324: 577.112 .6$

\section{CORRESPONDING AUTHOR}

e-mail: igor.zamorskii@gmail.com Zamorskii I.I.

Aminoglycosides are effective antibiotics, but their accumulation in kidney cortex causes nephrotoxic effects in 20-30\% of patients, which significantly limits their use. For this reason, search for the new therapies aimedat prevention of gentamicin-induced acute kidney injury (AKI) is highly relevant. Thus, the objective of our research was to study the functional and histopathological changes in kidneys of rats with gentamicininduced $A K I$, and estimate the renoprotective potential of pineal hormone melatonin, which possesses antioxidant, anti-inflammatory and immunomodulatoryeffects. The study was conducted on 24 non-linear male rats. Gentamicin-induced AKI was modeled by daily administration of $4 \%$ gentamicin sulphate $(80 \mathrm{mg} / \mathrm{kg})$ for 6 days. Melatonin (Sigma Aldrich, USA) was injected daily at a dose of $5 \mathrm{mg} / \mathrm{kg}$. Functional state of kidneys was assessed by diuresis, creatinine clearance, urine protein excretion, fractional excretion of sodium, and plasma potassium level. Documentation of the pathological processes was performed by the computer morphometry of objects in histological preparations. Statistical analysis of the data was performed using SPSS 17.0 software. Administration of gentamicin resulted in a significant impairment of renal function of experimental animals. A decrease in creatinine clearance by 3.1 times along with a reduction of diuresis by 1.9 times, and an increase in plasma creatinine concentration by 2.6 times was observed. There also was an increase in urine protein level by 5.2 times, an elevation of fractional sodium excretion and a reduction of plasma potassium level. Use of melatonin caused a significant improvement of renal function comparing to model pathology group. Functional disturbances were accompanied with the significant histopathological changes in kidney tissue: necrosis of the $27.0 \pm 5.2 \%$ epithelial cells of proximal tubules with the signs of hydropic vacuolization $(7.0 \pm 2.1 \%)$ or reversible hydropic swelling $(76.0 \pm 1.5 \%)$ in the rest of cells; swelling or deformation of some glomeruli. In the medulla tubular lumen were dilated and partially filled with hyaline casts, tubular cells had signs of dystrophy. Use of melatonin contributed to the restraint of the histopathological changes, confirmed by the decrease of the prevalence and severity of tubular necrosis (1.2\%), dystrophy $(64.0 \pm 2.3 \%)$, and injury of glomeruli. Obtained results verify the significant nephroprotective effect of pineal hormone melatonin, providing a background for the further in-depth study of its renal effects as well as its prospects as a nephroprotector. Keywords: gentamicin-induced acute kidney injury, histopathological changes, melatonin, nephroprotection.

\section{Introduction}

Aminoglycoside antibiotic gentamicin is widely used for the treatment and prophylaxis of Gram negative bacterial infections, though development of nephrotoxicity in 20$30 \%$ of patients significantly limits its use $[2,17,20,23]$.

Toxic influence of gentamicin on kidneys results from its accumulation in kidney cortex, where its concentration exceeds by more than 100 -fold its serum level. Due to its proximal tubular reabsorption gentamicin is accumulated in lysosomes of cells, inhibiting phospholipase and sphingomyelinase and leading to lysosomal phospholipidosis, accumulation of myeloid particles and cellular necrosis $[2,4]$. It is also stated the interaction between gentamicin and prostaglandins, leading to decrease in glomerular filtration rate (GFR) [6]. It is verified that local oxidative stress in tubular cells plays a central role in pathogenesis of aminoglycosides toxicity $[1,4,6$, 
7]. Gentamicin increases production of reactive oxygen species in mitochondria, which in turns inhibit respiratory chain activity and ATP production, stimulate release of cytochrome $\mathrm{C}$ and other proapoptotic factors, and disturb cellular functions by direct damage to proteins, lipids and nucleic acids, induce contraction of mesangial cells, cause dysfunction of endoplasmic reticulum, take part in development of inflammation. It results in disturbances of transmembrane transport of sodium ions, resulting in swelling and necrosis of cells [4, 17, 21]. Histological examination of experimental animals kidneys and biopsy of human kidneys reveals the swelling of proximal tubular cells, loss of brush border and tubular irregularity, as well as changes in intracellular organelles after one week of gentamicin use at therapeutic doses $[3,21]$.

Numerous experimental data verify an ability of antioxidants to limit a degree of kidney injury by aminoglycoside antibiotics due to minimization of direct toxic influence of gentamicin, prevention of vasoconstriction and contraction of mesangial cells, as well as anti-inflammatory effect $[1,2,4,7-12,18$, 20]. In this regard we focused our attention on melatonin as a possible remedy of pathogenetic correction of gentamicininduced acute kidney injury (AKI) due to its antioxidant, antiinflammatory and immunomodulatory effects [2, 6, 15, 25], which is confirmed by some studies [14, 15, 24]. Thus, use of pineal hormone may be considered as a potential therapeutic method of toxic AKI prevention.

Therefore, the objective of our research was to study the influence of melatonin on the histology and function of rats with gentamicin-induced AKI with estimation of its renoprotective potential.

\section{Materials and methods}

The study was conducted on 24 non-linear male rats weighting $130-180 \mathrm{~g}$, maintained in the vivarium conditions with constant temperature and humidity, free access to water and food. Animals were randomly divided into 3 groups $(n=8)$ : I group - intact control, II group - gentamicin-induced nephropathy, modeled by daily intramuscular administration of 4\% gentamicin sulphate (Galychpharm JSC, Ukraine) at a dose of $80 \mathrm{mg} / \mathrm{kg}$ for 6 days [22]. Melatonin (Sigma Aldrich, USA) was injected intraperitoneally at a dose of $5 \mathrm{mg} / \mathrm{kg} 40$ min after every gentamicin injection [15]. Animals were sacrificed $24 \mathrm{~h}$ after last injection, while blood, urine samples and kidneys were collected for biochemical and histopathological assessments. All interventions were conducted in accordance with the criteria outlined in the European Union Directive 2010/63/EU "On the protection of animals used for scientific purposes" (2010).

Functional state of kidneys was assessed by diuresis, creatinine clearance, urine protein excretion, fractional excretion of sodium, and plasma potassium level [22]. Plasma and urine creatinine levels were determined using the Jaffe reaction; sodium and potassium levels - using electronic flame photometry method; urine protein content - using the sulfosalicylic acid precipitation test.
The kidneys of rats were fixed in $10 \%$ formalin, embedded in paraffin, sectioned at $5 \mathrm{mM}$ and then stained with hematoxylin and eosin. The preparations were evaluated using light microscopy and photographed (Olympus C740UZ photo camera, Japan, LUMAM-R8 microscope, LOMO, Russian Federation). Documentation of the pathological processes was performed by the computer morphometry of objects in histological preparations using computer software "VideoTest - Razmer 5.0" (LLC "VideoTest", Russian Federation).

Statistical analysis of the data was performed using SPSS 17.0 software. All data are represented as a mean \pm standard error of the mean $(\mathrm{M} \pm \sigma)$. Estimation of the differences between the samples was conducted using parametric Student's t-test and nonparametric Mann-Whitney U test. The values $p<0.05$ were considered statistically significant.

\section{Results}

Administration of gentamicin consecutively for 6 days resulted in a significant impairment of renal morphofunctional state of experimental animals (Tab. 1). A decrease in creatinine clearance by 3.1 times along with a reduction of diuresis by 1.9 times, and an increase in plasma creatinine concentration by 2.6 times was observed. There also was an increase in urine protein level by 5.2 times, an elevation of fractional sodium excretion and a reduction of plasma potassium level. Use of melatonin caused a significant improvement of renal function comparing to model pathology group.

Histopathological examination of rats with gentamicin nephropathy in comparison with intact control group (Fig. 1) revealed a significant impairment of kidney tissue structure, caused by toxic influence of gentamicin (Fig. 2). In the absence of cells without pathological changes, there is a necrosis $27.0 \pm 5.2 \%$ of cortical tubular epithelial cells with deformation, swelling and atrophy of some glomeruli (Fig. $2 \mathrm{~A})$. In the renal cortex $7.0 \pm 2.1 \%$ of epithelial cells exhibit signs of hydropic vacuolization, the remaining epitheliocytes $(76.0 \pm 1.5 \%)$ are in a state of reversible hydropic swelling. In the renal medulla (Fig. 2B) and papilla (Fig. 2C) tubular

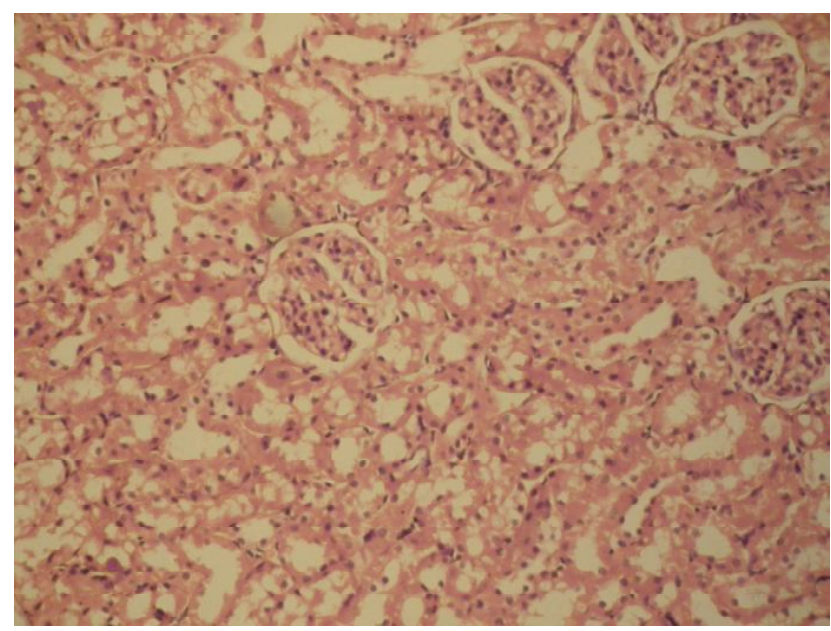

Fig. 1. Photomicrograph of kidney cortex section of intact rat (control). Staining with Haematoxylin and Eosin. (H\&E). x100. 

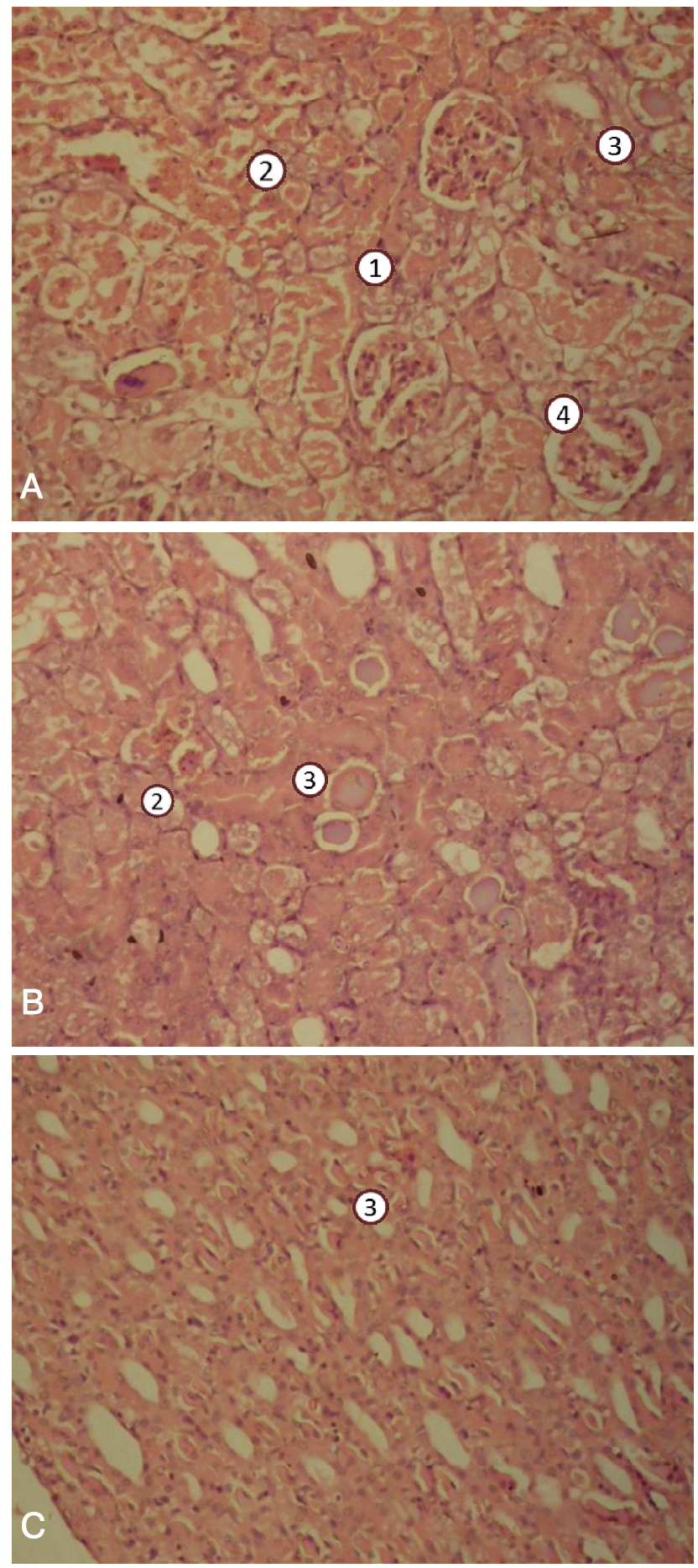

Fig. 2. Photomicrograph of kidney section (A - cortex, B medulla, C - papilla) of rat with gentamicin nephropathy, 7th day. Epithelial necrosis (1), epithelial degeneration (2), hyaline casts (3), dilation of Bowman's space (4). H\&E. x100.

cells degeneration, lumen dilation and deposition of hyaline casts are observed.

Melatonin co-administrationameliorated histopathological changes in kidneys. In the renal cortex areas of tubular epithelial necrosis are localized to $1.2 \%$, reversible hydropic
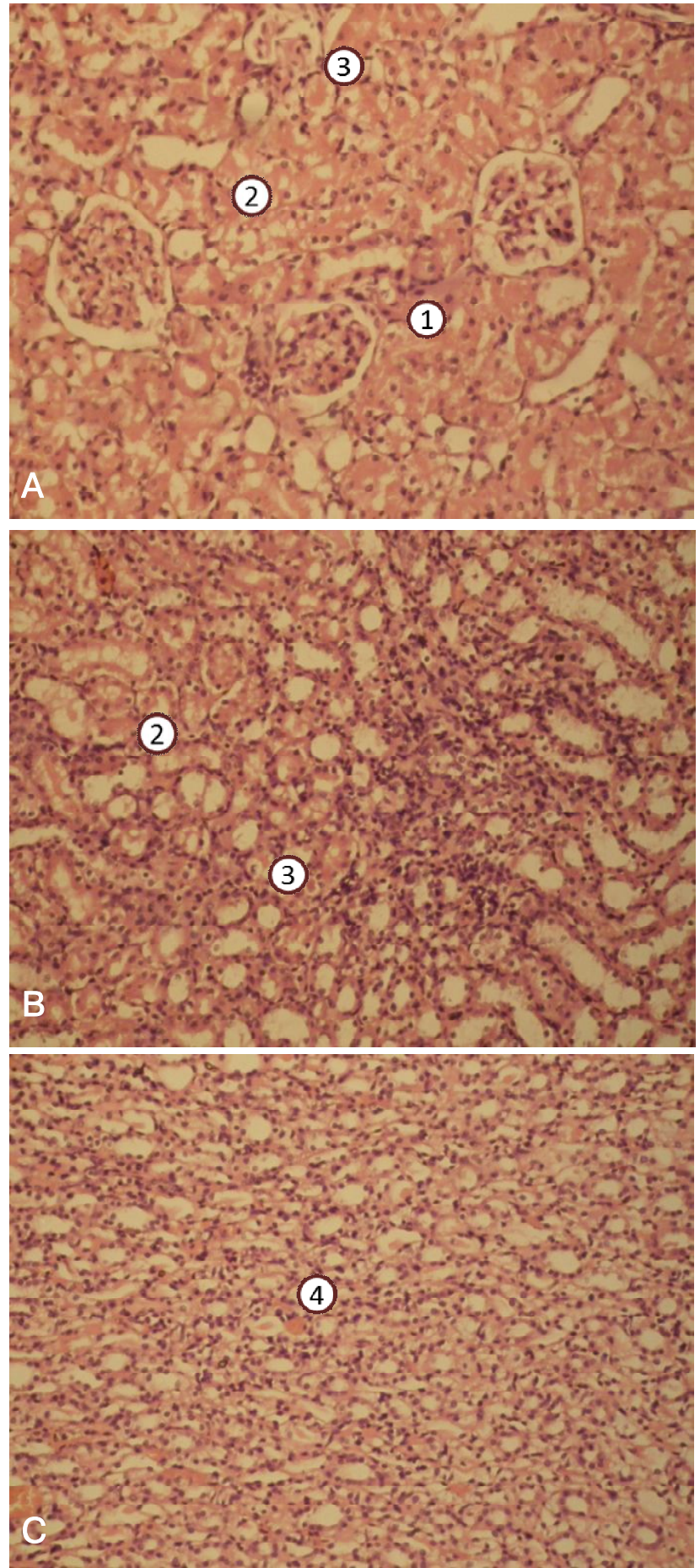

Fig. 3. Photomicrograph of kidney section (A - cortex, B - medulla, $C$ - papilla) of rat with gentamicin nephropathy and use of melatonin, $5 \mathrm{mg} / \mathrm{kg}$. Epithelial necrosis (1), epithelial degeneration (2), hyaline casts (3), hemorrage (4). H\&E. x100.

swelling is extended to $64.0 \pm 2.3 \%$ of proximal tubular epitheliocytes, with $4.0 \pm 1.6 \%$ of cells in a state of hydropic vacuolization, about $30.0 \%$ of the cells - without any signs of damage. Glomeruli of a normal structure and size, some with dilation of Bowman's space (Fig. 3A). Hyaline casts are 
present in small amounts in the renal cortex, medulla and papilla, there are also isolated hemorrhages (Fig. 3B, 3C).

\section{Discussion}

Gentamicin-induced nephrotoxicity at the beginning of the development of the pathological process is characterized by the development of oliguric form of renal failure, accompanied by retention azotemia, proteinuria, increased loss of sodium and potassium ions with urine, resulting in hypokalemia (Table 1), which reflects the significant damage and death of proximal tubular cells along with injury of glomeruli, and corresponds to the results of similar experimental studies of other authors [1, 4, 8-12, 17, 18]. According to the obtained results of the morphological examination, histopathological changes, namely the necrosis and degeneration of the proximal tubular epithelial cells in the form of vacuolization and hydropic dystrophy, and glomerular damage (Figure 2) were revealed for gentamicin nephropathy [3, 8-12, 14]. It is knownthat the most important mechanism of gentamicin nephrotoxicity is the hyperproduction of reactive oxygen species, causing damage to proteins, DNA and peroxidation of lipids, with an alteration of the integrity of cellular membranes and development of morphofunctional disorders [1, 17]. This fact conditions numerous research on the effectiveness of prevention of the gentamicin nephropathy, using known and new antioxidants [1, 2, 4, 8-12, 20].

Literature data point to the nephroprotective activity of melatonin in AKI due to kidney ischemia-reperfusion [13], burn disease [5], some toxic models [14, 15, 19]. Probably, the protective effect of melatonin is due to its potent antioxidant and anti-inflammatory properties, as well as the ability to suppress apoptosis $[6,16]$.

According to the results of our study, the use of melatonin at a dose of $5 \mathrm{mg} / \mathrm{kg}$ in the prophylactic treatment regimen (administration 40 min after each injection of gentamicin) does not completely prevent kidney damage by gentamicin, but leads to an improvement in renal function, which is confirmed by a significant increase in diuresis, creatinine clearance, concentration of potassium ions in plasma, along with a decrease in proteinuria and fractional excretion of sodium ions compared to non-treated animals (Table 1). At that, the maintenance of glomerular filtration may be explained by the direct antioxidant activity of the drug, since reactive oxygen species and nitrogen oxides directly lead to a decrease in GFR [16]. The established renal effects of melatonin in toxic kidney damage correspond to the criteria of nephroprotective action under the conditions of AKI development [2, 8-12].

The protective effect of melatonin has been realized in

\section{References}

[1] Adil, M., Kandhare, A., Dalvi, G., Ghosh, P., Venkata, S., Raygude, K., \&Bodhankar, S. (2016). Ameliorative effect of berberine against gentamicin-induced nephrotoxicity in rats via attenuation of oxidative stress, inflammation, apoptosis and mitochondrial dysfunction. Renal Failure, 38(6), 9961006. http://dx.doi.org/10.3109/0886022x.2016.1165120
Table 1. Influence of melatonin on the state of kidney excretory function in conditions of gentamicin-induced acutekidney injury $(\mathrm{M} \pm \sigma, \mathrm{n}=7)$.

\begin{tabular}{|c|c|c|c|}
\hline Index & Intact control & AKI & AKI+Melatonin \\
\hline $\begin{array}{c}\text { Diuresis, } \mathrm{ml} / 2 \\
\mathrm{~h} \times 100 \mathrm{~g}\end{array}$ & $4.649 \pm 0.193$ & $2.464 \pm 0.187^{\# \#}$ & $3.635 \pm 0.101^{\star *}$ \\
\hline $\begin{array}{c}\text { Plasma } \\
\text { creatinine, } \mu \mathrm{mol} / \mathrm{l}\end{array}$ & $59.67 \pm 3.92$ & $155.1 \pm 5.00^{\# \#}$ & $106.4 \pm 5.60^{\star \star}$ \\
\hline $\begin{array}{c}\text { Creatinine } \\
\text { clearence, } \\
\mathrm{ml} / \mathrm{min}\end{array}$ & $54.79 \pm 7.85$ & $17.54 \pm 1.94^{\# \#}$ & $30.29 \pm 2.44^{\star \star}$ \\
\hline Urine protein, g/l & $0.018 \pm 0.002$ & $0.093 \pm 0.007^{\# \#}$ & $0.058 \pm 0.005^{\star \star}$ \\
\hline $\begin{array}{c}\text { Fractional sodium } \\
\text { excretion, \% }\end{array}$ & $0.673 \pm 0.069$ & $3.426 \pm 0.716^{\# \#}$ & $1.781 \pm 0.198^{\star \star}$ \\
\hline $\begin{array}{c}\text { Plasma } \\
\text { potassium , } \\
\mu \mathrm{mol} / / \mathrm{l}\end{array}$ & $5.393 \pm 0.266$ & $4.357 \pm 0.261^{\# \#}$ & $5.036 \pm 0.127^{\star}$ \\
\hline
\end{tabular}

the limitation the severity and prevalence of histopathological changes in the kidneys, indicating the cytoprotective activity of this hormone in relation to nephrons, the ability of the drug to ameliorate the toxic effects of gentamicin and prevent the development of renal failure.

The obtained results substantiate the further in-depth study of the renal effects of melatonin on various experimental models of acute kidney injury, including those considering the chronobiological peculiarities of the hormone action, and the prospects of its use as a nephroprotector in acute kidney injury of different genesis.

\section{Conclusions}

1. A 6-day consecutive administration of gentamicin at a dose of $5 \mathrm{mg} / \mathrm{kg}$ leads to an alteration of the morphofunctional state of rats kidneys, which is manifested by the development of oliguric form of renal failure.

2. Structural organization of the renal tissue in gentamicininduced acute kidney injury is characterized by the occurrence of histopathological changes in both the glomerular and tubular apparatus of the nephron: necrosis of $27 \%$ of the epithelial proximal tubular cells and degenerative changes of various degrees of the remaining cells are observed.

3. According to research results, the protective effect of melatonin at a dose of $5 \mathrm{mg} / \mathrm{kg}$ is verified, which is manifested by restriction of nephrons damage and normalization of the structural organization of kidney tissue, as well as the preservation of renal function under the conditions of gentamicin-induced injury development.

[2] Ahmad, Q.Z., Jahan, N., Ahmad, G., \& Tajuddin (2014). An appraisal of nephroprotection and the scope of natural products in combating renal disorders. J. Nephrol. Ther. 4, 170. doi:10.4172/2161-0959.1000170

[3] Alarifi, S., Al-Doaiss, A. , Alkahtani, S., Al-Farraj, S., Al-Eissa, M., \& Al-Dahmash, B. (2012). Blood chemical changes 
and renal histological alterations induced by gentamicin in rats. Saudi Journal of Biological Sciences, 19(1), 103-110. http://dx.doi.org/10.1016/j.sjbs.2011.11.002

[4] Ali, B.H., Al Za'abi, M., Blunden, G., \& Nemmar, A. (2011). Experimental gentamicin nephrotoxicity and agents that modify it: a mini-review of recent research. BCPT. 109, 225232. doi:10.1111/j.1742-7843.2011.00728.x

[5] Bai, X.-Z., He, T., Gao, J.-X., Liu, Y., Liu, J.-Q., Han, S.-C., ... Hu, D. -H. (2016). Melatonin prevents acute kidney injury in severely burned rats via the activation of SIRT1. Scientific Reports, 6, 32199. http://doi.org/ 10.1038/srep32199

[6] Bharti, V. K., Srivastava, R. S., Subramaian, P., Warren Spence, D., Pandi-Perumal, S. R., Brown, G. M. (2011). Cerebral epiphyseal proteins and melatonin modulate the hepatic and renal antioxidant defense of rats. Intern. $J$ of Nephrology. Article ID 142896. doi:10.4061/2011/142896.

[7] Casanova, A., Vicente-Vicente, L., Hernandez-Sanchez, M., Pescador, M., Prieto, M., Martinez-Salgado, C. ... LopezHernandez, F.J. (2017). Key role of oxidative stress in animal models of aminoglycoside nephrotoxicity revealed by a systematic analysis of the antioxidant-to-nephroprotective correlation. Toxicology, 385, 10-17. http://dx.doi.org/ 10.1016/j.tox.2017.04.015

[8] Diwan, P., Kakalij, R., Alla, C., Kshirsagar, R., Kumar, B., \& Mutha, S. (2014). Ameliorative effect of Elaeocarpus ganitrus on gentamicin-induced nephrotoxicity in rats. Indian Journal Of Pharmacology, 46(3), 298. http://dx.doi.org/10.4103/ 0253-7613.132163

[9] Ehsani, V., Amirteimoury, M., Taghipour, Z., Shamsizadeh, A., Bazmandegan, G., Rahnama, A. ... Fatemi, I. (2017). Protective effect of hydroalcoholic extract of Pistacia vera against gentamicin-induced nephrotoxicity in rats. Renal Failure, 39(1), 519-525. http://dx.doi.org/10.1080/ 0886022x.2017.1326384

[10] Ghaznavi, H., Fatemi, I., Kalantari, H., Hosseini Tabatabaei, S., Mehrabani, M., Gholamine, B. ... Goudarzi, M. (2017). Ameliorative effects of gallic acid on gentamicin-induced nephrotoxicity in rats. J. of Asian Natural Products Research, 112. http://dx.doi.org/10.1080/10286020.2017.1384819

[11] Hajihashemi, S., Hamidizad, Z., Rahbari, A., Ghanbari, F., \& Motealeghi, Z. (2017). Effects of Cobalamin (Vitamin B12) on Gentamicin Induced Nephrotoxicity in Rat. Drug Research, 67(12), 710-718. http://dx.doi.org/ 10.1055/s-0043117418

[12] Kakalij, R. M., Alla, C. P., Kshirsagar, R. P., Kumar, B. H., Mutha, S. S., \& Diwan, P. V. (2014). Ameliorative effect of Elaeocarpus ganitrus on gentamicin-induced nephrotoxicity in rats. Indian Journal of Pharmacology, 46(3), 298-302. http://doi.org/10.4103/0253-7613.132163

[13] Kang, J., Koh, E., \& Lee, S. (2011). Melatonin protects liver against ischemia and reperfusion injury through inhibition of toll-like receptor signaling pathway. Journal of Pineal Research, 50(4), 403-411. http://dx.doi.org/10.1111/ j. 1600-079x.2011.00858.x

[14] Kapic, D., Mornjakovic, Z., Cosovic, E., Sahinovic, M. (2014).
A histological study of the effect of exogenous melatonin on gentamicin induced structural alterations of proximal tubules in rats. Bosnian J of Basic Medical Sciences. 14(1), 30-34. doi:10.17305/bjbms.2014.2293

[15] Kilic, U., Kilic, E., Tuzcu, Z., Tuzcu, M., Ozercan, I. H., Yilmaz, O., ... Sahin, K. (2013). Melatonin suppresses cisplatin-induced nephrotoxicity via activation of Nrf-2/HO1 pathway. Nutrition \& Metabolism, 10, 7. http://doi.org/ 10.1186/1743-7075-10-7.

[16] Lee, I., Kim, S., Lee, S., Baek, H., Moon, C., Kim, S. ... Kim, J.C. (2012). Melatonin attenuates gentamicin-induced nephrotoxicity and oxidative stress in rats. Archives of Toxicology, 86(10), 1527-1536. http://dx.doi.org/10.1007/ s00204-012-0849-8

[17] Lopez-Novoa, J. M., Quiros, Y., Vicente, L., Morales, A., \& Lopez-Hernandez, F.J. (2011). New insights into the mechanism of aminoglycoside nephrotoxicity: an integrative point of view. Kidney Intern., 79(1), 33-45. https://doi.org/ 10.1038/ki.2010.337

[18] Mahmoud, Y., \& Farag, S. (2017). Kiwifruit ameliorates gentamicin induced histological and histochemical alterations in the kidney of albino mice. Biotechnic \& Histochemistry, 92(5), 357-362. http://dx.doi.org/10.1080/10520295. 2017.1318222

[19] Onk, D., Onk, O. A., Turkmen, K., Erol, H. S., Ayazoglu, T. A., Keles, O. N., ... Topal, E. (2016). Melatonin Attenuates Contrast-Induced Nephropathy in Diabetic Rats: The Role of Interleukin-33 and Oxidative Stress. Mediators of Inflammation, 2016, 9050828. http://doi.org/10.1155/ 2016/9050828

[20] Pierson-Marchandise, M., Gras, V., Moragny, J., Micallef, J., Gaboriau, L., Picard, S. ... Liabeuf, S. (2017). The drugs that mostly frequently induce acute kidney injury: a case noncase study of a pharmacovigilance database. British Journal of Clinical Pharmacology, 83(6), 1341-1349. http:// dx.doi.org/10.1111/bcp.13216

[21] Randjelovic, P., Veljkovic, S., Stojiljkovic, N., Sokolovic, D., \& Ilic, I. (2017). Gentamicin nephrotoxicity in animals: Current knowledge and future perspectives. EXCLI Journal, 16, 388-399. http://doi.org/10.17179/excli2017-165

[22] Singh, A. P., Junemann, A., Muthuraman, A., Jaggi, A. S., Singh, N., Grover, K., \& Dhawan, R. (2012). Animal models of acuterenal failure. Pharmacol. Reports, 64, 31-44.

[23] Srisung, W., Teerakanok, J., Tantrachoti, P., Karukote, A., \& Nugent, K. (2017). Surgical prophylaxis with gentamicin and acute kidney injury: a systematic review and metaanalysis. Annals of translational medicine, 5(5), 100-101. http://dx.doi.org/10.21037/atm.2017.03.06

[24] Tavakoli, M. (2014). Kidney protective effects of melatonin. Journal of Nephropharmacology, 3(1), 7-8.

[25] Tordjman, S., Chokron, S., Delorme, R., Charrier, A., Bellissant, E., Jaafari, N., \& Fougerou, C. (2017). Melatonin: Pharmacology, Functions and Therapeutic Benefits. Current Neuropharmacology, 15(3), 434-443. http://doi.org/ $10.2174 / 1570159 \times 14666161228122115$

МОРФОФУНКЦІОНАЛЬНІ ЗМІНИ НИРОК ЩУРІВ ПРИ ЗАСТОСУВАННІ МЕЛАТОНІНУ НА ТЛІ РОЗВИТКУ

ГЕНТАМІЦИН-ІНДУКОВАНОГО ГОСТРОГО ПОШКОДЖЕННЯ НИРОК

Дудка Є.А., Заморський І.І., Петрюк А.Є., Щудрова Т.С.

Аміноглікозиди є ефективними антибіотиками, але їх накопичення в кірковій речовині нирки викликає нефротоксичні ефекти у 20-30\% пацієнтів, що значно обмежує їх застосування. 3 цієї причини актуальним є пошук нових профілактичних заходів, спрямованих на запобігання гострому пошкодженню нирок (ГПН), спричиненому гентаміцином. Таким чином, метою нашого дослідження було вивчення функціональних і гістопатологічних змін у нирках щурів при гентаміцин-індукованому ГПН з оцінкою нефропротекторного потенціалу пінеального гормону мелатоніну, який володіє антиоксидантними, протизапальними 
та імуномодулюючими ефектами. Дослідження проводили на 24 нелінійних самцях щурів. Гентаміцин-індуковане ГПн моделювали щоденним введенням 4\% гентаміцину сульфату (80 мг/кг) протягом 6 днів. Мелатонін (Sigma Aldrich, CШA) вводили щодня у дозі 5 мг/кг. Функціональний стан нирок оцінювали за показниками діурезу, кліренсу креатиніну, екскреції білка з сечею, фракційної екскреції іонів натрію та концентрації іонів калію в плазмі крові. Документацію патологічних процесів здійснювали за допомогою комп'ютерної морфометрії об'єктів у гістологічних препаратах. Введення гентаміцину призвело до значного погіршення функції нирок у дослідних тварин. Виявлено зниження кліренсу креатиніну в 3,1 рази, зменшення діурезу в 1,9 рази, збільшення концентрації креатиніну в плазмі в 2,6 рази. Також спостерігалося збільшення вмісту білка у сечі в 5,2 рази, підвищення фракційної екскреції іонів натрію та зниження концентрації іонів калію в плазмі. Показано, що використання мелатоніну викликало значне покращення ниркової функції порівняно з групою модельної патології. Виявлено, що функціональні розлади супроводжувалися значними гістопатологічними змінами в тканинах нирок: некроз епітеліальних

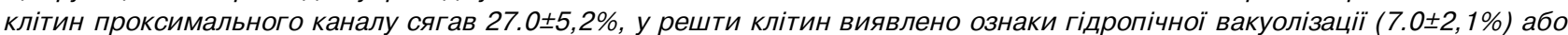

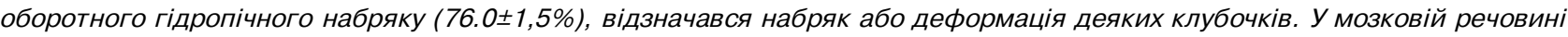
просвіти канальців розширені і частково заповнені гіаліновими циліндрами, канальцеві клітини з ознаками дистрофії. Показано, що використання мелатоніну сприяло обмеженню гістопатологічних змін, що підтверджується зменшенням поширеності та

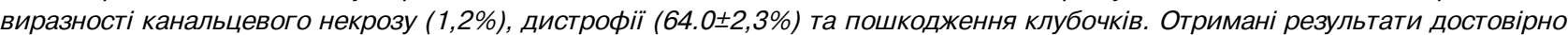
підтверджують нефропротекторний ефект пінеального гормону мелатоніну, що є підгрунтям для подальшого поглибленого вивчення його реальних ефектів, а також перспектив його застосування як нефропротектора.

Ключові слова: гентаміцинова нефропатія, мелатонін, гістопатологічні зміни, нефропротекція.

\section{МОРФОФУНКЦИОНАЛЬНЫЕ ИЗМЕНЕНИЯ ПОЧЕК КРЫС ПРИ ПРИМЕНЕНИИ МЕЛАТОНИНА НА ФОНЕ РАЗВИТИЯ ГЕНТАМИЦИН-ИНДУЦИРОВАННОГО ОСТРОГО ПОВРЕЖДЕНИЯ ПОЧЕК Дудка Е.А., Заморский И.И., Петрюк А.Е., Щудрова Т.С.}

Аминогликозиды являются эффективными антибиотиками, но их накопление в корковом веществе почек вызывает нефротоксические эффекты у 20-30\% пациентов, что значительно ограничивает их использование. По этой причине актуальным является поиск новых профилактических средств, способных предотвращать гентамицин-индуцированное острое повреждение почек (ОПП). Таким образом, целью нашего исследования было изучение функциональных и гистопатологических изменений в почках крыс при гентамицин-индуцированном ОПП с оценкой нефропротекторного потенциала пинеального гормона мелатонина, обладающего антиоксидантными, противовоспалительными и иммуномодулирующими свойствами. Исследование проводили на 24 нелинейных крысах-самцах. Гентамицининдуцированное ОПП моделировали ежедневным введением 4\% гентамицина сульфата (80 мг/кг) в течение 6 дней. Мелатонин (Sigma Aldrich, США) вводили ежедневно в дозе 5 мг/кг. Функциональное состояние почек оценивали по показателям диуреза, клиренса креатинина, экскреции белка с мочой, фракционной экскреции ионов натрия и концентрации ионов калия в плазме крови. Документацию патологических процессов проводили путем компьютерной морфометрии объектов в гистологических препаратах. Введение гентамицина привело к значительному ухудшению функции почек у подопытных животных. Выявлено снижение клиренса креатинина в 3,1 раза, уменьшение диуреза в 1,9 раза, увеличение концентрации креатинина в плазме в 2,6 раза. Также наблюдалось увеличение содержания белка в моче в 5,2 раза, повышение фракционной экскреции натрия и снижение концентрации ионов калия в плазме. Показано, что использование мелатонина вызвало значительное улучшение почечной функции по сравнению с группой модельной патологии. Выявлено, что функциональные нарушения сопровождались значительными гистопатологическими изменениями в ткани почек: некроз эпителиальных клеток проксимальных канальцев достигал $27.0 \pm 5,2 \%$, в других клетках выявлены признаки гидропической

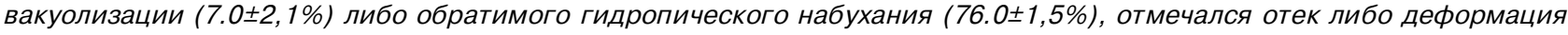
некоторых клубочков. В мозговом веществе просветы канальцев расширены и частично заполнены гиалиновыми цилиндрами, канальцевые клетки с признаками дистрофии. Показано, что использование мелатонина способствовало ограничению гистопатологических изменений, что подтверждается снижением распространенности и выраженности

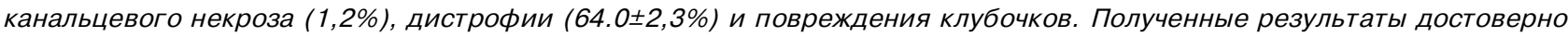
подтверждают нефропротекторное действие пинеального гормона мелатонина, обосновывая его дальнейшее углубленное изучение реальных эффектов, а также перспективы использования как нефропротектора.

Ключевые слова: гентамицин-индуцированная нефропатия, мелатонин, гистопатологические изменения, нефропротекция. 